\title{
Serum Cystatin C dan Kreatinin dalam Mendiagnosis Gangguan Ginjal Akut pada Anak Sakit Kritis
}

\author{
Pratita Jati Permatasari, ${ }^{*}$ Aumas Pabuti, ${ }^{*}$ Eti Yerizel, ${ }^{* *}$ Fitrisia Amelin* \\ *Departemen Ilmu Kesehatan Anak Fakultas kedokteran, ** Pascasarjana Ilmu Biomedik Fakultas Kedokteran Universitas Andalas/ \\ RSUP Dr. M. Djamil Padang
}

Latar belakang. Gangguan ginjal akut (GgGA) berhubungan dengan mortalitas dan morbiditas yang tinggi di antara anak sakit
kritis. Cystatin $\mathrm{C}$ adalah protease inhibitor yang menurut beberapa penelitian merupakan biomarker yang baik untuk mendeteksi
gangguan ginjal akut pada anak sakit kritis. Tujuan. Mengetahui sensitivitas, spesifisitas, nilai prediksi positif, dan nilai prediksi negatif cystatin $C$ serum dan kreatinin serum dalam mendiagnosis gangguan ginjal akut pada anak sakit kritis.

Metode. Penelitian potong lintang pada 70 subjek di HCU dan PICU RSUP. Dr. M. Djamil Padang dari Mei 2017 - Juni 2017. Subjek penelitian laki-laki 55,71\%, median usia 16,50 bulan. Subjek dipilih dengan teknik konsekutif. Dilakukan pemeriksaan cystatin $C$ serum dengan ELISA dan kreatinin dengan kolorimetrik. Baku emas menggunakan estimasi laju filtrasi glomerulus berdasarkan formula Schwartz. Gangguan ginjal akut terjadi bila terjadi penurunan laju filtrasi glomerulus minimal 25\% berdasarkan kriteria pRIFLE. Kurva receiver operating characteristic (ROC) digunakan untuk menilai cystatin $C$ dan kreatinin dalam mendiagnosis GgGA. Hasil. Rerata cystatin $C$ dan kreatinin serum pada GgGA 0,88 $\pm 0,14 \mathrm{mg} / \mathrm{L}, 1,13 \pm 0,59 \mathrm{mg} / \mathrm{dL}$ berturut-turut. Tiga puluh tujuh pasien didiagnosis GgGA. Cut off point cystatin C serum 0,56 mg/L, sensitivitas 85,19\%, spesifisitas 60,47\%, nilai prediksi positif 57,50\%, nilai prediksi negatif $13,33 \%$. Cut off point kreatinin serum $0,95 \mathrm{mg} / \mathrm{dL}$, sensitivitas $51,85 \%$, spesifisitas $100 \%$, nilai prediksi positif $100 \%$, nilai prediksi negatif $23,21 \%$.

Kesimpulan. Cystatin $C$ serum sensitif untuk mendiagnosis GgGA tetapi kurang spesifik. Sari Pediatri 2018;20(2):95-100

Kata kunci: cystatin $C$ serum, gangguan ginjal akut, sakit kritis

\section{Serum Cystatin C and Serum Creatinine for Diagnosing Acute Kidney Injury in Critically Ill Children}

Pratita Jati Permatasari, ${ }^{*}$ Aumas Pabuti, ${ }^{*}$ Eti Yerizel, ${ }^{* *}$ Fitrisia Amelin*

Background. Acute kidney injury (AKI) has been associated with high morbidity and mortality rates among critically ill children. Cystatin $\mathrm{C}$ is a protease inhibitor, and studies have shown that it is promising marker for diagnosing AKI in critically ill children. Objective. To assess specificity, sensitivity, positive predictive value, and negative predictive value of serum cystatin $\mathrm{C}$ and creatinine for diagnosing AKI in critically ill children.

Methods. A cross-sectional study was conducted on 70 patients at PICU and HCU of Dr. M. Djamil Hospital Padang from May 2017 to June 2017. Fifty five-point seventy one percent patients were boys and median aged group was 16,50 months old. The samples were selected consecutively. Serum cystatin C was examined by ELISA while serum creatinine was examined by colorimetric. Estimated glomerular filtration rate by using Schwartz formula was the gold standard. Acute kidney injury was diagnosed by modified pRIFLE criteria. Receiver operating characteristic (ROC) curve analysis was performed to assess the utility of serum cystatin C and creatinine for diagnosing AKI.

Results. Serum cystatin C, serum creatinine (mean \pm standart deviation) in AKI group were $0,88 \pm 0,14 \mathrm{mg} / \mathrm{L}, 1,13 \pm 0,59 \mathrm{mg} / \mathrm{dL}$, respectively. Thirty seven patients was diagnosed AKI. Serum cystatin C sensitivity with cutoff value $0,56 \mathrm{mg} / \mathrm{L}$ was $85,19 \%$, specificity $60,47 \%$, positive predictive value $57,50 \%$, negative predictive value $13,33 \%$. Serum creatinine sensitivity with cut off value 0,95 mg/ dL was $51,85 \%$, specificity $100 \%$, positive predictive value $100 \%$, negative predictive value $23,21 \%$.

Conclusions. Serum cystatin C was sensitive for diagnosing AKI but less specific. Sari Pediatri 2018;20(2):95-100

Keywords: serum cystatin C, AKI, critically ill

Alamat korespondensi: Pratita Jati Permatasari. Departemen Ilmu Kesehatan Anak FK-UNAND/RSUP dr.M.Djamil Jl.Perintis Kemerdekaan. Padang, Sumatera Barat.Email: tt.merkusie@gmail.com 
Pratita Jati, dkk: Serum cystatin C dan kreatinin dalam mendiagnosis gangguan ginjal akut anak sakit kritis

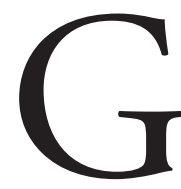

angguan ginjal akut (GgGA) adalah gangguan fungsi ginjal akut yang ditandai peningkatan kadar ureum dan kreatinin serum, dengan atau tanpa penurunan produksi urin. ${ }^{1}$.

Insiden GgGA pada anak sakit kritis bervariasi antara 8-30\% dengan angka kematian sekitar 37$80 \%{ }^{2,3}$ Studi lain melaporkan pada anak yang dirawat di PICU mencapai $82 \%$ bila menggunakan kriteria pRIFLE. ${ }^{4}$ Angka mortalitas meningkat seiring dengan peningkatan stadium, yaitu risk 18,9\%, injury $36,1 \%$ dan failure 46,4\%. ${ }^{5}$ Saat ini belum ada laporan mengenai insiden GgGA di Indonesia. ${ }^{5}$ Penelitian Nilawati menunjukkan 6,1\% pasien yang dirawat di PICU rumah sakit Sanglah Denpasar. ${ }^{6}$ Data yang diperoleh dari $7^{\text {th }}$ report of Indonesia renal registry, 30 orang pasien di Sumatera Barat membutuhkan tindakan hemodialis. ${ }^{7}$ Jumlah pasien GgGA di bangsal anak RSUP Dr. M. Djamil selama 2 tahun terakhir 107 pasien. ${ }^{8}$

Penegakan diagnosis GgGA pada anak menggunakan kriteria pediatric Risk, Injury, Failure, Loss, and End stage renal disease (pRIFLE) berdasarkan kreatinin serum dan keluaran urin. Penggunaan kreatinin serum untuk menilai LFG memiliki beberapa kelemahan, yaitu baru meningkat setelah terjadi penurunan fungsi ginjal hingga 50\% atau lebih dan dipengaruhi oleh beberapa faktor di luar ginjal, seperti berat badan, massa otot, ras, usia, jenis kelamin, obat-obatan, metabolisme otot, dan asupan protein. ${ }^{1,9}$ Penegakan diagnosis GgGA dengan hanya mengukur keluaran urin juga memiliki kelemahan karena obat nefrotoksik dan penyakit ginjal intersisial menghasilan keluaran urin normal atau meningkat. ${ }^{5}$

Cystatin $C$ adalah suatu protein berat molekul rendah $(13 \mathrm{kDa})$ yang disintesis pada semua sel berinti. Cystatin $C$ merupakan anggota dari superfamili cystatin yang memiliki fungsi sebagai inhibitor protease sistein.

Cystatin $C$ difiltrasi secara bebas oleh glomerulus, direabsorbsi oleh tubulus dan tidak disekresi, tetapi mengalami katabolisme hampir lengkap (99\%) oleh sel tubulus proksimal sehingga tidak ada yang kembali ke darah. Dengan demikian, kadar cystatin $C$ dalam darah menggambarkan laju filtrasi glomerulus (LFG) dan dapat dikatakan mendekati penanda LFG endogen yang ideal. ${ }^{10}$ Penelitian yang dilakukan oleh Herget-Rosenthal $\mathrm{dkk}^{11}$ pada 85 pasien sakit kritis yang dirawat di intensive care unit (ICU) menunjukkan bahwa cystatin $C$ mendeteksi GgGA 1,5 hari lebih cepat daripada serum kreatinin sehingga cystatin $C$ dapat digunakan untuk deteksi dini GgGA.
Diagnosis yang tepat dan deteksi dini GgGA di PICU sangat diperlukan untuk mengatur pemberian cairan, penyesuaian dosis obat dan mencegah gangguan ginjal yang lebih lanjut. ${ }^{12}$ Berdasarkan hal tersebut di atas peneliti tertarik untuk mengetahui nilai cystatin $C$ serum dan kreatinin serum sebagai diagnosis gangguan ginjal akut pada anak sakit kritis di RS dr. M. Djamil Padang.

\section{Metode}

Penelitian ini merupakan uji diagnostik dengan rancangan potong lintang. Penelitian dilakukan di High Care Unit (HCU) dan PICU bangsal anak RS Dr. M. Djamil Padang serta Laboratorium Biomedik Fakultas Kedokteran Universitas Andalas Padang dari Mei 2017 - Juni 2017.

Populasi penelitian seluruh anak sakit kritis yang dirawat di HCU dan PICU RSUP Dr. M Djamil Padang dari Mei 2017 - Juni 2017 dan subjek penelitian adalah bagian dari populasi yang memenuhi kriteria inklusi dan eksklusi. Jumlah subjek penelitian adalah 70 orang. Pengambilan sampel dilakukan dengan cara konsekutif sampling. Kriteria inklusi adalah Semua pasien usia 1 bulan sampai 14 tahun yang sudah dirawat di PICU atau HCU selama 48 jam dan orang tua atau wali pasien bersedia ikut dalam penelitian. Kriteria eksklusi adalah pasien yang menderita hipotiroid atau hipertiroid, mendapat terapi metil prednisolon puls, menderita keganasan, mendapat terapi siklosporin A, mendapat terapi simetidin atau trimethoprim. Subjek penelitian yang memenuhi kriteria inklusi dan eksklusi diambil darah vena 6 cc untuk diperiksa kreatinin serum dan cystatin c serum. Kreatinin serum diperiksa dengan metode kolorimetrik menggunakan spektrofotometer, sedangkan cystatin $C$ serum diperiksa menggunakan metode enzyme linked immunosorbent assay (ELISA). Baku emas penelitian ini menggunakan estimasi laju filtrasi glomerulus berdasarkan formula Schwartz. Gangguan ginjal akut didiagnosis dengan kriteria pRIFLE. Gangguan ginjal akut didefinisikan bila terjadi penurunan LFG minimal 25\% dalam 48 jam rawatan.

\section{Hasil}

Total subjek penelitian adalah 70 orang anak yang berusia 1 bulan sampai 14 tahun yang memenuhi kriteria inklusi dan kriteria eksklusi. Berdasarkan jenis 
kelamin, didapatkan $39(55,7 \%)$ subjek penelitian berjenis kelamin laki-laki dan 31 (44,3\%) perempuan. Rata-rata umur subjek penelitian adalah 39,03 bulan.

Median usia kelompok GgGA adalah 26 bulan, sedangkan pada kelompok non-GgGA adalah 7 bulan. Kejadian GgGA tidak dipengaruhi oleh usia dan jenis kelamin dengan nilai p sebesar 0,09 dan 0,08 berturutturut. Berdasarkan kriteria pRIFLE 27 pasien $(38,6 \%)$ mengalami GgGA dengan klasifikasi 5 pasien risk, 12 pasien injury, dan 10 pasien failure. Penyakit dasar yang paling banyak menyebabkan GgGA adalah penyakit neurologi $(12,9 \%)$, diikuti oleh infeksi $(8,6 \%)$. Karakteristik subjek penelitian tertera pada Tabel 1 .
Rerata kadar cystatin $C$ pada kelompok GgGA adalah $0,88 \pm 0,14 \mathrm{mg} / \mathrm{L}$ dan kelompok non GgGA adalah $0,47 \pm 0,07 \mathrm{mg} / \mathrm{L}$. Berdasarkan statistik didapatkan perbedaan bermakna kadar cystatin $C$ serum pada kelompok GgGA dan kelompok non GgGA dengan nilai $p=0,001$. Rerata kadar kreatinin serum pada kelompok GgGA adalah $1,13 \pm 0,59 \mathrm{mg} /$ dL dan kelompok non GgGA adalah 0,36 $\pm 0,09 \mathrm{mg} /$ dL. Didapatkan perbedaan bermakna kadar kreatinin serum antara kelompok GgGA dan non GgGA dengan nilai $\mathrm{p}=0,001$

Dari hasil analisis menggunakan kurva ROC diperoleh bahwa AUC untuk cystatin $C$ serum adalah

Tabel 1. Karakteristik subjek penelitian

\begin{tabular}{|c|c|c|c|c|c|}
\hline \multirow[t]{2}{*}{ Variabel } & \multicolumn{2}{|c|}{$\begin{array}{c}\text { GgGA } \\
n=27\end{array}$} & \multicolumn{2}{|c|}{$\begin{array}{c}\text { Non GgGA } \\
n=43\end{array}$} & \multirow[t]{2}{*}{ Nilai $p$} \\
\hline & $\begin{array}{l}\text { Median } \\
(\text { min-max })\end{array}$ & n (\%) & $\begin{array}{l}\text { Median } \\
(\text { min-max })\end{array}$ & n (\%) & \\
\hline Usia & $26(1-156)$ & & $7(1-168)$ & & 0,09\# \\
\hline \multicolumn{6}{|l|}{ Jenis kelamin } \\
\hline Laki & & $11(28,2)$ & & $28(71,8)$ & $0,08^{\varphi}$ \\
\hline Perempuan & & $16(51,6)$ & & $15(48,4)$ & \\
\hline LFG & $39,37(23-117)$ & & $110(77-206)$ & & $0,001^{*}$ \\
\hline \multicolumn{6}{|l|}{ pRIFLE } \\
\hline Risk & & $5(18,5)$ & & & \\
\hline Injury & & $12(44,4)$ & & & \\
\hline Failure & & $10(37,1)$ & & & \\
\hline \multicolumn{6}{|l|}{ Penyakit dasar } \\
\hline Neurologi & & $9(12,9)$ & & $12(17,1)$ & \\
\hline Infeksi & & $6(8,6)$ & & $7(10)$ & \\
\hline Hematologi & & $4(5,7)$ & & $10(14,3)$ & \\
\hline Gastrohepatologi & & $4(5,7)$ & & $0(0)$ & \\
\hline Respirologi & & $2(2,9)$ & & $14(20)$ & \\
\hline Nefrologi & & $1(1,4)$ & & $0(0)$ & \\
\hline Trauma & & $1(1,4)$ & & $(0)$ & \\
\hline
\end{tabular}

\# uji Mann-Whitney ${ }^{\varphi}$ uji chi-square * uji T-test

Tabel 2. Kadar rerata cystatin $C$ serum dan kreatinin serum

\begin{tabular}{lccc}
\hline Variabel & $\begin{array}{c}\text { GgGA } \\
\text { Mean } \pm S D\end{array}$ & $\begin{array}{c}\text { Non GgGA } \\
\text { Mean } \pm S D\end{array}$ & $p$ \\
\hline Cystatin C & $0,88 \pm 0,14$ & $0,47 \pm 0,07$ & $0,001^{*}$ \\
Kreatinin & $1,13 \pm 0,59$ & $0,36 \pm 0,09$ & $0,001 \#$ \\
\hline
\end{tabular}

* uji T-test \# uji Mann-Whitney 
ROC Curve

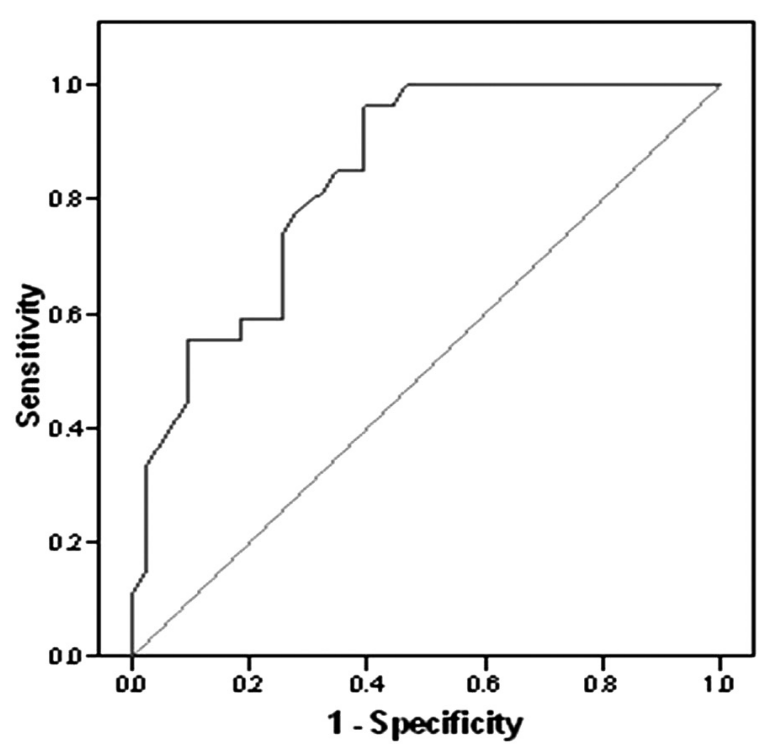

Gambar 1. Kurva ROC cystatin C serum terhadap GgGA

\section{Roc Curve}

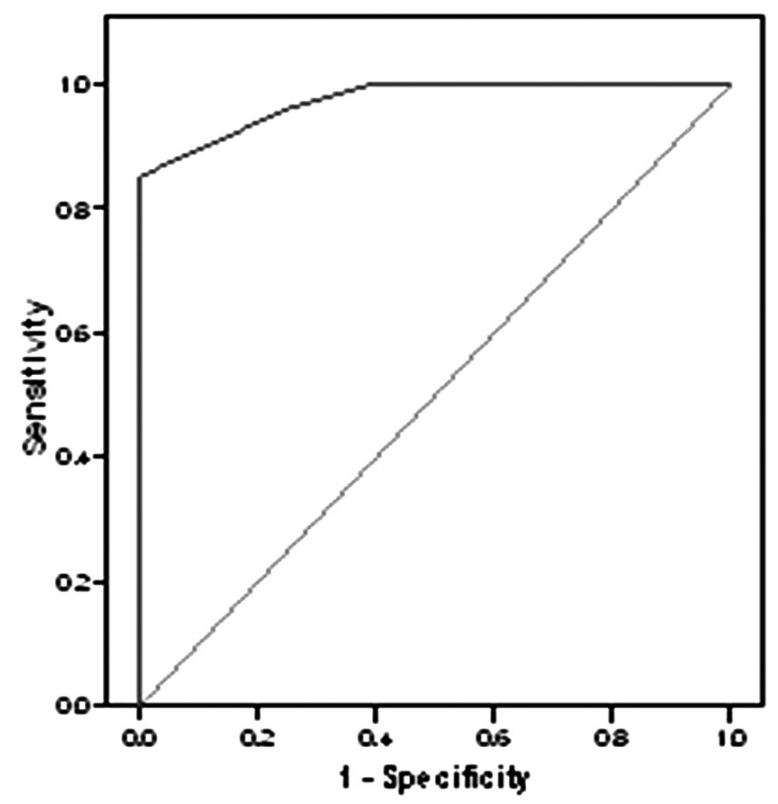

Gambar 2. Kurva ROC kreatinin serum terhadap GgGA

0,839 (IK95\% 0,750-0,925). Nilai cut off point cystatin $C$ serum adalah $0,56 \mathrm{mg} / \mathrm{L}$ dengan sensitivitas $85 \%$, spesifitas $61 \%$, nilai prediksi positif $57,50 \%$, dan nilai prediksi negatif $13,33 \%$
AUC untuk kreatinin serum adalah 0,951 (95\% CI 0,893-1,000). Nilai cut off point kreatinin serum adalah $0,95 \mathrm{mg} / \mathrm{dL}$ dengan sensitivitas $52 \%$, spesifitas $100 \%$, nilai prediksi positif $100 \%$, dan nilai prediksi negatif $23,21 \%$.

\section{Pembahasan}

Penelitian ini merupakan uji diagnostik dengan rancangan potong lintang yang dilakukan pada 70 orang anak sakit kritis yang memenuhi kriteria inklusi dan eksklusi. Jumlah subjek penelitian anak perempuan 31 dan laki-laki 39 orang. Median usia adalah 16,5 bulan. Berdasarkan usia dan jenis kelamin pada pasien dengan GgGA dan non GgGA tidak didapatkan perbedaan. Sesuai dengan penelitian sebelumnya oleh Ataei $\mathrm{dkk}^{12} \mathrm{di}$ Iran dan. Safdar dkk ${ }^{13}$ di Saudi Arabia yang melaporkan bahwa tidak terdapat perbedaan kejadian GgGA berdasarkan jenis kelamin dan usia. Insiden GgGA pada anak sakit kritis dengan menggunakan kriteria pRIFLE bervariasi antara 10\%-58\%. ${ }^{14}$ Pada penelitian ini, 38,6\% anak didagnosis GnGA.

Uji beda cystatin $C$ serum dan kreatinin serum antara pasien GgGA dan non GgGA menunjukkan hasil yang berbeda. Hal tersebut sesuai dengan penelitian yang dilakukan Murty $\mathrm{dkk}^{18}$ pada 120 pasien GgGA dan 200 orang non GgGA di India. Murty dkk melaporkan terdapat perbedaan bermakna kadar cystatin $C$ serum dan kreatinin serum antara kelompok GgGA dan non GgGA. Meskipun keduanya menunjukkan hasil berbeda, simpang baku cystatin $C$ lebih kecil daripada kreatinin. Hal tersebut menunjukkan bahwa variabilitas cystatin $C$ serum lebih kecil daripada kreatinin serum. Produksi kreatinin serum dipengaruhi oleh massa otot dan faktor diet. Kreatinin difiltrasi oleh glomerulus dan disekresi oleh tubulus ginjal. Sekresi tubulus sekitar 20\% dari total kreatinin yang diekskresi ginjal sehingga kreatinin kurang menggambarkan nilai LFG yang sebenarnya terutama bila terjadi penurunan LFG minimal.

Rerata kadar cystatin $C$ normal pada anak sehat antara $0,65 \pm 0,19$. Pada penelitian ini didapatkan kadar rerata cystatin $C$ serum pasien non $\mathrm{GgGA}$ lebih rendah daripada nilai rujukan cystatin $C$ pada anak sehat. Hal tersebut disebabkan karena sampel penelitian adalah pasien sakit kritis yang seringkali mengalami "nonthyroidal illness" sehingga kadar cystatin C serum akan menurun. ${ }^{15}$ 
Pemantauan gangguan fungsi ginjal sangat penting dalam tata laksana anak sakit kritis. Baku emas untuk menentukan LFG adalah dengan mengukur kliren zat dari eksogen seperti inulin, chromium 51-diethylenetria minepentaacetic acid (DTPA), Tc-ethylenediaminetetra acetic acid (EDTA), ioheksol, dan I-labeled iothalamate. Metode pengukuran LFG dengan zat eksogen ini sulit dilakukan karena invasif, membutuhkan waktu yang lama, dan mahal sehingga pengukuran LFG dengan substansi endogen banyak digunakan dalam praktek klinis sehari-hari. ${ }^{16}$ Pada penelitian ini, kami memilih menggunakan rumus Schwartz untuk mengukur estimasi LFG sebagai standar baku emas karena sampai saat ini rumus tersebut yang disepakati oleh UKK nefrologi untuk menilai fungsi ginjal. ${ }^{1}$

Sensitivitas kreatinin serum $51,85 \%$ dan spesifisitas $100 \%$. Sensitivitas kreatinin yang rendah ini disebabkan karena kreatinin baru meningkat setelah terjadi penurunan fungsi ginjal lebih dari $50 \%$. Faktor lain yang menyebabkan kreatinin rendah pada anak sakit kritis adalah turunnya produksi kreatinin, asupan kreatinin diet yang kurang, dan gangguan fungsi hepar. ${ }^{17}$ Pada kelompok GgGA, $48,15 \%$ pasien memiliki nilai kreatinin serum normal yang disebut sebagai "creatinine blind area". Pada "creatinine blind area" ini serum kreatinin normal, sedangkan cystatin $C$ serum meningkat. ${ }^{18}$ Hal tersebut menunjukkan bahwa kadar cystatin $C$ serum sudah naik sebelum kadar kreatinin serum mulai naik. Spesifitas serum kreatinin 100\% dengan nilai prediksi positif $100 \%$. Hal tersebut menunjukkan bahwa bila nilai kreatinin positif maka kemungkinan menderita GgGA sebesar 100\% dan telah terjadi kerusakan tubulus ginjal yang berat. ${ }^{19}$ Spesifisitas kreatinin yang tinggi ini juga dipengaruhi oleh nilai cut off kreatinin serum yang cukup tinggi. ${ }^{19}$ Penelitian ini mendukung penelitian yang dilakukan oleh Shoukath $\mathrm{dkk}^{20}$ di India pada 100 orang pasien sakit kritis. Shoukath melaporkan spesifitas dan nilai prediksi positif sebesar $100 \%$.

Pengukuran cystatin $C$ serum dalam 24 jam pertama merupakan prediktor GgGA yang sensitif pada anak sakit kritis. Hal tersebut dibuktikan dengan sensitivitas cystatin C 85,19\% dibandingkan dengan sensitivitas kreatinin yang hanya $51,85 \%$. Penelitian ini mendukung penelitian sebelumnya yang dilakukan oleh Herrero-Morin $\mathrm{dkk}^{21}$ yang melaporkan bahwa cystatin $C$ serum dan beta-2 mikroglobulin lebih berhubungan dengan kliren kreatinin daripada serum kreatinin pada anak GgGA yang dirawat di PICU. Kadar cystatin $C$ serum akan meningkat ketika LFG turun $88-95 \mathrm{ml} / \mathrm{mnt}$ per $1,73 \mathrm{~m}^{2}$ sehingga dapat mendeteksi gangguan fungsi ginjal 24-48 jam sebelum kreatinin. ${ }^{12}$

Pada penelitian ini didapatkan cutoff point cystatin C 0,56 mg/L dengan sensitivitas $85 \%$ dan spesifisitas $51,85 \%$. Penelitian ini juga didukung oleh penelitian yang dilakukan oleh Safdar dkk $^{13}$ di Saudi Arabia. Safdar dkk meneliti peran cystatin $C$ sebagai biomarker baru untuk mendeteksi GgGA pada 62 anak sakit kritis yang dirawat di PICU Rumah Sakit King Abdul Aziz Saudi Arabia. Safdar dkk ${ }^{13}$ melaporkan bahwa cutoff point terbaik untuk cystatin $C$ serum adalah 0,645 mg/L dengan AUC 0,843 (IK95\%: 0,732$0,953)$ dan didapatkan nilai sensitivitas $94 \%$ dengan spesifisitas $60 \%$. Safdar menyimpulkan bahwa cystatin $C$ serum merupakan biomarker yang sensitif, tetapi tidak spesifik dalam mendiagnosis GgGA pada anak sakit kritis. Spesifitas cystatin $C$ yang kurang karena kadar serum cystatin $C$ dipengaruhi oleh beberapa faktor, seperti kondisi hipotiroid atau hipertiroid, terapi steroid, hormon pertumbuhan dan insulin. Pada penelitian ini, meskipun kondisi hipotiroid atau hipertiroid termasuk dalam kriteria eksklusi, untuk mendiagnosis kondisi tersebut hanya berdasarkan kondisi klinis tanpa dilakukan pemeriksaan hormon tiroid.

Salah satu kelemahan mengapa cystatin $C$ masih belum digunakan secara luas adalah masalah harga. Harga pemeriksaan cystatin $C$ cukup mahal bila dibandingkan dengan pemeriksaan kreatinin. Bila kita telaah lebih lanjut, apabila GgGA dapat dideteksi lebih awal maka kita dapat melakukan pencegahan dan proteksi fungsi ginjal dari perburukan lebih lanjut sehingga pasien berpeluang lebih besar untuk terhindar dari penggunaan modalitas terapi pengganti ginjal (TPG). Deteksi dini GgGA diharapkan dapat meningkatkan luaran pasien, mengurangi angka mortalitas, dan mengurangi lama waktu rawat yang pada akhirnya dapat menghemat biaya rawat pasien. Idealnya, diketahui berapa hari cystatin $C$ lebih cepat mendeteksi GgGA dibandingkan dengan serum kreatinin.

Penelitian ini memiliki beberapa kelemahan, yaitu definisi GgGA berdasarkan perubahan estimasi LFG yang dihitung dengan formula Schwartz dan tidak diperiksa faktor yang memengaruhi kadar cystatin $C$ seperti kadar hormon tiroid. 
Pratita Jati, dkk: Serum cystatin C dan kreatinin dalam mendiagnosis gangguan ginjal akut anak sakit kritis

\section{Kesimpulan}

Penelitian ini menyimpulkan rerata kadar cystatin $C$ serum dan kreatinin serum lebih tinggi pada kelompok GgGA dibandingkan dengan kelompok non GgGA. Sensitivitas cystatin $C$ serum lebih tinggi daripada kreatinin serum dalam mendiagnosis GgGA pada anak sakit kritis. Akan tetapi spesifitas cystatin $C$ serum lebih rendah dibandingkan dengan kreatinin serum dalam mendiagnosis GgGA pada anak sakit kritis. Peneliti menyarankan untuk dilakukan penelitian lanjutan berupa penelitian kohort untuk mengetahui berapa hari cystatin Clebih cepat mendiagnosis GgGA dibandingkan dengan kreatinin serum dan dilakukan pemeriksaan faktor-faktor yang memengaruhi kadar cystatin $C$ serum seperti hormon tiroid.

\section{Daftar pustaka}

1. Noer MS, Soemyarso NA, Subandiyah K, Prasetyo RV. Rekomendasi gagal ginjal akut pada anak: UKK Nefrologi IDAI;2014.

2. Chan JC, William DM, Roth KS. Kidney Failure in infant and children. Pediatr Rev 2002;23:47-60.

3. Mehta P, Sinha A, Sami A. Incidence of acute kidney injury in hospitalized children. India Pediatr 2012;49:537-42.

4. Pudjiadi A, Yuniar I. Gagal ginjal akut. Dalam: Pudjiadi AH, Latief A, Budiwardhana N, penyunting. Buku ajar pediatri gawat darurat. Jakarta: Badan Penerbit Ikatan Dokter Anak Indonesia; 2013.h.133-40.

5. Pardede SO, Puspaningtyas NW. Kriteria rifle pada acute kidney injury. Majalah Kedokt FKUI 2012;28:92-102

6. Nilawati GAP. Kejadian acute kidney injury dengan kriteria pRIFLE pada unit perawatan intensif anak rumah sakit Sanglah Denpasar. Sari Pediatri 2012:158-61.

7. Pernefri 7th report Indonesia renal registry. Jakarta: 2014 .

8. Annur R, Pabuti A, Amelin F. Clinical spectrum and outcome acute kidney injury in pediatric ward. 2017.

9. Villa P, Jimenez M, Soriano MC, Manzanares J, Cassasnovas P. Serum cystatin $\mathrm{C}$ concentration as a marker of acute renal dysfunction in critically ill patient. Crit Care 2005;9:139-43.

10. Bokenkamp A, Filler G, Hofman W, Bricon TL, Martinez BC, Grub A. Review Cystatin C as a marker of GFR-History, Indication, and Future Research. Clin Biochem 2005;8:1-8.

11. Herget-Rosenthal S, Marggraf G, Husing J, Goring f, Pietruck F, Jansen O, dkk. Early detection of acute renal failure by serum cystatin C. Kidney Int 2004;66:1115-22.

12. Ataei N, Bagargani B, Ameli S, Madani A, Javadilarijani F, Moghtaderi M, dkk. Early detection of acute kidney injury by serum cystatin C in critically ill children. Pediatr Nephrol 2013:1-5.

13. Safdar Osama, Shalaby Mohammed, Khathlan Norah, Elattal Bassem, Bin Joubah Mohammed, Bukhari Esraa, dkk. Serum cystatin is a useful marker for the diagnosis of acute kidney injury in critically ill children: prospective cohort study. BMC Nephrol 2016;17:1-8.

14. Akcan-Arikan A, Zapitelli M, Loftis LL, Jefferson LS, Goldstein SL. Modified RIFLE criteria in critically ill children with acute kidney injury. Kidney Int 2007;71:1026-35.

15. Wulkan R, Hollander J, Berghout A. Cystatin C: unsuited to use as a marker of kidney function in intensive care unit. Crit Care 2005;9:531-2.

16. Stevens LA, Coresh J, Greene T, Levey AS. Assessing kidney function-measured and estimated glomerular filtration rate. N Eng J Med 2006;354:2473-83.

17. Sagheb MM, Namazi S, Geramizadeh B, Karimzadeh A, Oghazian MB, Karimzadeh I. Serum cystatin C as marker of renal function in critically ill patients with normal serum creatinine. Nephro Urol Mon 2014;6:e152224.

18. Murty MS, Sharma UK, Kankare SB. Serum cystatin C as a marker of renal function in detection of early acute kidney injury. Indian J Nephrol 2013;23:180-3.

19. Waikar S, Betensky R, Emerson S, boventre JV. Imperfect gold standards for kidney injury biomarker evaluation. J Am Soc Nephrol 2012;23:13-21.

20. Shoukath AR, Patil S. Serum cystatin C concentration levels as a marker of acute renal failure in critically ill patient - a cross section study. Al ameen J Med Sci 2014;7:65-71.

21. Herrero-Morin JD, Malaga S, Fernandez N, Rey C, Dieguez MA, Solis G, dkk. Cystatin C and beta 2-microglobulin: markers of glomerular filtration in critically ill children. Crit Care 2007;11:R59. 